\title{
RESUME
}

\section{AUDIT SISTEM INFORMASI ABSENSI PADA PT. BANK CENTRAL ASIA TBK MENGGUNAKAN COBIT 4.1}

\author{
Johanes Fernandes Andry \\ Program Studi Sistem Informasi, Universitas Bunda Mulia Jl. Lodan Raya No. 2 Ancol, \\ Jakarta Utara.
}

\begin{abstract}
Perkembangan sistem informasi sampai saat ini telah mendukung proses bisnis diberbagai perusahaan, seperti penggunaan sistem informasi absensi pada PT. Bank Central Asia.Tbk (BCA). Untuk itu diperlukan suatu evaluasi atas penggunaan sistem informasi absensi yang dimiliki BCA untuk memastikan bahwa sistem informasi yang dimiliki telah memberi kemudahan bagi perusahaan.
\end{abstract}

Metode COBIT dapat berguna untuk teknologi informasi membuat hubungan kerja kebutuhan bisnis, organisasi teknologi informasi dapat membuat proses model, mengidentifikasi suber daya teknologi informasi, dapat mengarahkan objektif kontrol Manajemen.

COBIT membantu menyokong pengembangan kebijakan yang jelas dan langkah-langkah praktis terbaik yang dapat diambil untuk pengendalian teknologi informasi di seluruh perusahaan. COBIT dirancang antara lain untuk mendukung Manajemen eksekutif dan dewan direksi serta Bisnis dan manajemen teknologi informasi.

Metodologi penelitian yang dilakukan dan tahapan-tahapan penulis dalam mengambil ataupun memperoleh data dari sumber, mulai dari survei awal, wawancara dan kuisioner. Lingkup dari penelitian ini dibatasi pada audit sistem informasi absensi pada PT.Bank Central Asia,Tbk khususnya pada Kantor Cabang Pembantu (KCP) Mangga Besar, Jakarta dan Identifikasi Proses Sistem Informasi Absensi. Pada tahap ini, menetapkan proses teknologi informasi yang sesuai dengan standar COBIT yang telah diolah sesuai dengan studi kasus. Cakupan IT domain yang di audit pada sistem informasi absensi, diperlihatkan pada Tabel I Cakupan IT Domain Yang Di Audit.

Prosedur Penelitian merupakan suatu kegiatan yang harus dilakukan dalam melakukan penelitian. Adapun tahapan dan prosedur penelitiannya adalah Planning (Perencanaan), Field Work (Pemeriksaan Lapangan), Reporting (Pelaporan), dan Follow-Up (Tindak Lanjut).

Audit Sistem Informasi Absensi Pada PT. Bank Central Asia Tbk Menggunakan Cobit 4.1 sudah dilakukan walaupun masih belum berjalan secara optimal karena belum mencapai pada tingkat kematangan yang diharapkan. Tingkat kematangan (maturity level) yang ada pada setiap proses TI yang terdapat dalam sub-domain Al4 dan DS4 masih dibawah 3 yaitu 2.25 dan 2.4 pada level Repeatable but Intuitive \& untuk sub domain DS1, DS5, DS10 dan ME2 sudah pada level 3 yaitu Defined Process. Proses tata kelola sistem absensi telah memiliki pola yang berulangkali dilakukan. 
Di dalam melakukan manajemen aktivitas terkait dengan tata kelola teknologi informasi, namun keberadaannya sudah terdefinisi secara baik dan formal sehingga masih perlu perlu ditingkatkan lagi. Evaluasi tata kelola $\mathrm{TI}$ ini disarankan dapat dilakukan secara rutin setiap periode waktu tertentu (secara periodik), agar tingkat kematangan yang diinginkan dapat dicapai.

Ditulis oleh:

Mohamad Fajar Rizky Siregar

NPM $195100061 P$

Program Studi Sistem Informasi

Fakultas Komputer

Universitas Mitra Indonesia 